\title{
Theistic Replies to the A Priori Argument for Atheism
}

\section{Klaas J. Kraay}

Ryerson University

digital.library.ryerson.ca/object/385

Please Cite:

Kraay, K. J. (2005). Theistic replies to Rowe's a priori argument for atheism. Philo, 8(1), 23-37.

doi:10.5840/philo20058115

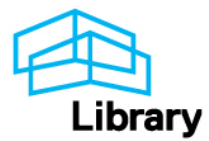




\section{Theistic REPlies to THE A PRIORI ARgument FOR ATHEISM*}

Klaas J . Kraay

Ryerson University

This paper first appeared in Philo 8 (2005): 22-36. It was subsequently reprinted as Chapter 13 of Wainwright, W. [Ed.] (2010) Philosophy of Religion: Critical Concepts in Philosophy, New York: Routledge, pp. 238-253.

ABSTRACT: In the central chapter of Can God Be Free?, William Rowe offers what amounts to an a priori argument for atheism. In what follows, I first clarify this argument, and I then defend it against recent criticisms due to William Hasker. Next, however, I outline four ways in which theists might plausibly reply to Rowe's argument.

In the central chapter of his important new book, Can God Be Free?, William Rowe suggests that theism is precluded by the conjunction of two claims: one is a certain principle concerning improvability, and the other holds that there is no best world that God can create. In several places, Rowe expresses this view by claiming that three propositions form an inconsistent set. The clearest articulation is given on page 120: ${ }^{1}$

\begin{tabular}{|ll|}
\hline A & There necessarily exists an essentially omnipotent, essentially omniscient, \\
essentially perfectly good being who has created a world. \\
B If an omniscient being creates a world when there is a better world that it could \\
have created, then it is possible that there exists a being morally better than it \\
(emphasis added). \\
C For any creatable world there is a better creatable world.
\end{tabular}

Rowe suggests that B - the principle concerning improvability - is plausible, and claims that since the set is inconsistent, anyone inclined to assert $\mathrm{C}$ should give up $\mathrm{A} .{ }^{2}$

In my view, each of these claims should be reformulated. A refers to essential perfect goodness, but it would be clearer to speak of essential unsurpassability, since this is how Rowe understands divine goodness (82-83). Also, while Rowe ultimately aims to reduce to absurdity the doctrine of moral unsurpassability, a similar argument could be advanced against rational unsurpassability, ${ }^{3}$ so that attribute should be listed in A. And, A is expressed too strongly: Rowe's argument, if sound, shows not only that an essentially unsurpassable being cannot exist necessarily, but that such a being cannot possibly exist.4

As for "Principle B", this claim conflates two propositions which should be kept distinct. $\mathrm{B}$ expresses a certain connection between the goodness of the product ${ }^{5}$ of some action and the goodness of the agent, but this suppresses the traditional distinction between, on the one hand,

\footnotetext{
* This paper was originally presented at an "Author-Meets-Critics" session on Can God Be Free?, at the Central Division Meeting of the American Philosophical Association, Chicago, April 28, 2005. Thanks are due to all participants in this session, especially William Rowe; to Austin Dacey for organizing it; and to Nathan Ballantyne for helpful comments on an earlier draft. I gratefully acknowledge the generous research support I received from the Social Sciences and Humanities Research Council of Canada (SIG program) and Ryerson University in Winter 2005.
} 
the link between the goodness of a product and the goodness of the action which led to that product, and on the other hand, the relationship between the goodness of an action and the goodness of the agent. 6

Finally, Rowe's C could be made more precise. Ultimately, Rowe means to conclude that A is false, given B and C, but this can sound paradoxical: if many worlds are creatable by God, then - given B - God cannot create any world. ${ }^{7}$ This result can be avoided by replacing $\mathrm{C}$ with a restricted claim about God's power: for any world w that God has the power to actualize, there is a better world, $\mathrm{x}$, that God has the power to actualize instead. ${ }^{8}$ (This is hereafter termed the hypothesis of no prime worlds, or NPW. ${ }^{9}$ ) It says nothing about whether divine moral properties constrain God's choice of world to actualize, which leaves Rowe free to claim that the doctrine of essential divine moral unsurpassability is incoherent, given this view of possible worlds and divine power. Here, then, is a revised version of Rowe's inconsistent set:

\begin{tabular}{|l} 
G There possibly exists a being who is essentially unsurpassable in power, \\
knowledge, goodness, and rationality. \\
P1 If it is possible for the product of a world-actualizing action performed by some \\
being to have been better, then, ceteris paribus, it is possible for that being's \\
action to have been better. 10 \\
P2 If it is possible for the world-actualizing action performed by some being to have \\
been better, then, ceteris paribus, it is possible for that being to have been better. \\
NPW $\begin{array}{l}\text { For every world w that is within God's power to actualize, there is a better world, } \\
\text { x, that God has the power to actualize instead. }\end{array}$
\end{tabular}

Propositions in this set may be deployed, straightforwardly, in a valid argument which reduces G to absurdity. ${ }^{11}$ (This amounts to an a priori argument for the impossibility of theism on NPW.) But is this argument sound? Or, to put the point differently, given that this set is inconsistent, which member(s) should be rejected? Rowe thinks that P1 and P2 should be accepted, and that anyone inclined to assert NPW should reject G. ${ }^{12}$ In what follows, I first consider an important exchange between Rowe and one of his critics, William Hasker. ${ }^{13}$ I conclude that Hasker's criticism of Rowe fails, but not for the reasons Rowe gives. In the second section of the paper, I sketch four more promising objections to Rowe.

\section{ROWE'S REPLY TO WILLIAM HASKER}

\subsection{HASKER'S OBJ ECTION}

For a few years now, a lively and fruitful exchange has developed between two eminent Bills: Rowe and Hasker. ${ }^{14}$ The most recent moves are expressed in a paper in Hasker's new anthology, ${ }^{15}$ a reply by Rowe in Chapter 6, Section IV, of Can God Be Free?, followed by a rejoinder by Hasker, published in an Appendix to his anthology. The 'wedge issue' here is the following claim, due to Thomas Morris: failing to do better than one did is a defect only if doing the best one can is possible for one to do. ${ }^{16}$ 'Purdue-Bill' deems this claim false, while 'Huntington-Bill' thinks it true. Here are the latter's reasons:

Given the no-best-world hypothesis (which for present purposes we will take as established), it is logically impossible for God to "do the best he can" and because this is a necessary truth, God's failure to do the best he can is not in any way a moral fault or failing on God's part. This much is agreed to by all concerned. However, it is also true that God "failed to do better than he did" (that is, failed to create a world better than the present actual world) ... [and] the only 
way that he could be freed from the charge of "failing to do better than he did" is if there were a maximally excellent world, one than which even God could not create a better. But that is, by hypothesis, impossible; the no-best-world assumption precludes it. This, however, means that, whatever world God should create, it is a necessary truth that he could have created a better one; in this sense, it is a necessary truth that God "failed to do better than he did". But as has already been established with regard to God's "doing his best," the failure to contravene a necessary truth is no kind of moral fault, whether in God or in anyone else. ${ }^{17}$

[A] "fault" that is logically impossible to avoid is no fault at all; it is not a moral defect ... It is quite true that, on the assumption of no best world, God has created a world less good than some other world he could have created. The question that needs to be asked, however, is whether this alleged "fault" is one it was logically possible to avoid. The answer, of course, is that it was not, and so it is not a fault at all."18

In the Appendix to his anthology, Hasker offers a more formal expression of this argument: ${ }^{19}$

(1) If, necessarily, I fail to do the best I can, then, necessarily, I fail to do better than I actually did. ${ }^{20}$

(2) If, necessarily, I fail to do the best I can, then failing to do the best I can is not a moral fault.

(3) If, necessarily, I fail to do better than I actually did, then failing to do better than $I$ actually did is not a moral fault.

(4) If, necessarily, I fail to do the best I can, then failing to do better than I actually did is not a moral fault.

Conclusion (4) follows from (1) and (3), and (3) is defended on the basis of its structural similarity to the uncontroversial (2).

How, exactly, does this pertain to Rowe's argument? If Hasker's (4) is true, then God should not be faulted for failing to do better, with respect to world-actualization, on NPW. And this, in turn, suggests that either P1 or P2 is false. Accordingly, if Hasker's argument is sound, it blocks Rowe from arguing, on the basis of P1, P2, and NPW, that G is false. After criticizing Rowe's stated reply to Hasker, I will offer a different criticism, which undercuts the parallel Hasker means to draw between (2) and (3). I conclude that Hasker has not proven (4), and, accordingly, that his argument cannot be deployed to defeat Rowe's a priori argument for atheism on NPW.

\subsection{ROWE'S REPLY CRITICIZED}

Hasker claims that Rowe has not challenged any of premises (1)-(3), and even says that Rowe explicitly accepts them. I'm not so sure about that, ${ }^{21}$ but first let's look at Rowe's reply, which seems to have two main parts:

(a) Rowe repeats the thought-experiment according to which a creator actualizes the least good creatable world (109). ${ }^{22}$ He then claims that Hasker's argument must contain a mistake, since it implausibly suggests that the creator, in this scenario, is in no way surpassable. By itself, Rowe's move here is not especially satisfying, since it does not show exactly where Hasker's argument fails: it merely underscores the conflict of intuitions which divides them.

(b) Rowe introduces a distinction between the (putative) general defect of creating some world or other which is worse than a better creatable world, and the (real) particular defect of 
creating a world w, when a better world, x could have been created in its stead (108-110). Rowe appears to think that a creator should not be thought surpassable for exemplifying the general defect, but that a creator should be thought surpassable for exemplifying the particular defect. ${ }^{23}$ So far as I can tell, Rowe means to concede that Hasker's premise (3) is true if understood to concern the general defect, while insisting that (3) false if understood to concern the particular defect.) I'm not convinced that this distinction can defeat Hasker's objection: I tend to agree with Hasker that "...if it is not wrong, or otherwise morally defective, for a being to perform an act of [general] kind $K$, then any particular action a is not wrong or morally defective in virtue of its being of kind $K$, though of course a might be wrong for some other reason". ${ }^{24}$

Rowe's official reply to Hasker, then, not decisive.

\subsection{A SiMPLER REPLY TO HASKER}

Fortunately (for 'Purdue-Bill'), a much simpler strategy is available. Rowe can affirm Hasker's (2) while denying Hasker's (3), without invoking the difficult distinction between general and particular defects. Recall that Hasker's central move is to note that on NPW, it is a necessary truth both that God fails to do his best, and that God fails to do better than he does. ${ }^{25}$ In the quotations displayed above, Hasker reasons that in both cases, "the failure to contravene a necessary truth is no kind of moral fault". ${ }^{26}$ But this is a mistake. The reason why God is not to be blamed for failing to do his best (i.e. actualize the best possible world) on NPW is that this is a logically impossible task - which is just to say that there simply is no task at all to perform. ${ }^{27}$ In contrast, however, God's doing better than he does (i.e. actualizing a better world) is a logically possible task - and this is true no matter what world God actualizes. This crucial difference best explains why God's failure to contravene one necessary truth is not a 'fault', while God's failure to contravene another is a 'fault'. ${ }^{28}$ Accordingly, Hasker has not established (3) on the basis of its similarity to (2), which means that he has offered no reason to believe (4). And this, in turn, means that Hasker's argument provides no motivation to deny either P1 or P2.

\section{THEISTIC REPLIES TO ROWE}

Suppose that the theist concedes the revised set of propositions to be inconsistent: ${ }^{29}$

G There possibly exists a being who is essentially unsurpassable in power,
knowledge, goodness, and rationality, who has created the world.
P1 If it is possible for the product of a world-actualizing action performed by some
being to have been better, then, ceteris paribus, it is possible for that being's
action to have been better.
P2 If it is possible for the world-actualizing action performed by some being to have
been better, then, ceteris paribus, it is possible for that being to have been better.
NPW For every world w that God has the power to actualize, there is a better world, $\mathrm{x}$,
that God
has the power to actualize instead.

As noted, Rowe thinks that P1 and P2 are plausible, and so he argues that on NPW, G should be rejected. Given that Hasker's criticism fails, how else might the theist reply? In what follows, I briefly sketch four (non-exclusive) strategies. ${ }^{30}$ 


\subsection{CRITICISM OF ROWE'S DEFENCE OF P1AND P2}

The first reply is modest: it merely aims to remove the grounds Rowe offers for belief in P1 and P2. As noted, Rowe "Principle B" conflates these, so to develop this reply, we must consider what Rowe says in favour of this key principle, which he takes to be a necessary truth (97). Interestingly, it proves difficult to ascertain exactly what direct support Rowe means to offer for it. (Much of Chapter 6 consists in Rowe's offering indirect support for Principle B, by answering objections to it.) For one thing, much of what Rowe says, perhaps seemingly in its defence, in fact provides no independent support. ${ }^{31}$ Also, it seems that Rowe has recently weakened his stance on one way to support B: in a 2002 paper, with reference to Thomas Morris' expression thesis ("the goodness of an agent's actions is expressive of the agent's goodness") Rowe held that he was ".. inclined to take something like this thesis as underlying the claim expressed in Principle B", 32 but in the book, Rowe now says that he is ".. inclined to think that something like this thesis is related to the claim expressed in Principle B" (100, emphasis added). In any case, Morris' expression thesis can support - at most - P2, not B.

As far as I can tell, the most compelling direct consideration Rowe offers in favour of B is a kind of parity argument: Rowe chides theists who assume or endorse something like this principle when they claim that God must actualize a prime world (if such there be), but then reject it on NPW (120-1, 124-5). But I don't think that this point is decisive. Many of our intuitions about finite sets fail to transfer to infinite sets, and so while some theist's allegiance to $\mathrm{B}$ in one case may give some reason to expect similar allegiance (from the same theists) in another case, this hardly settles the matter.

Rowe's direct case for Principle B, then, is unpersuasive. But interestingly, Rowe seems confident in several places that no argument is needed: he says that this principle is "plausible, if not self-evident"; that it has "intuitive appeal"; and that, on this basis, it should be presumed true $(89,124)$. The theist need not concede this. But even if she does, she might well reply that the same is true of $\mathrm{G}$ in the set displayed above. On this view, granting NPW for the sake of argument, Rowe's claims concerning Principle B do not provide adequate reason to maintain P1 and $\mathrm{P} 2$ at the expense of G. ${ }^{33}$

\subsection{INDEPENDENT ARGUMENTS FOR G.}

At most, the reply just described can show that Rowe has not succeeded in supporting P1 and P2 to the detriment of G. By itself, then, this is not decisive. Suppose, however, that the theist concedes that Rowe is entitled to deem P1 and P2 prima facie plausible, or even to some degree justified. Given that the set $\{\mathrm{G}, \mathrm{NPW}, \mathrm{P} 1, \mathrm{P} 2\}$ is inconsistent, how else might she respond? Granting NPW for the sake of argument, the theist might well hold that she has stronger reasons for believing $\mathrm{G}$ than Rowe has for believing P1 and P2. Rowe recognizes that something like this move is a legitimate option for the theist (121). But Rowe has in mind his version of the inconsistent set:
A There necessarily exists an essentially omnipotent,
essentially perfectly good being who has created a world.
B If an omniscient being creates a world when there is a better world that it could have created, then it is possible that there exists a being morally better than it.
C For any creatable world there is a better creatable world.

If (as I argued above) I am right that A should be replaced with $\mathrm{G}$, and $\mathrm{B}$ with $\mathrm{P} 1 \& \mathrm{P} 2$, then the theist who wishes to exercise this option bears a lighter burden of proof than Rowe realizes: instead of requiring equal or better reasons for believing $\mathrm{A}$ than she has for $\mathrm{B}$, she must have 
equal or better reasons for believing that God is possible than she has for believing the conjunction of $\mathrm{P} 1$ and $\mathrm{P} 2 .{ }^{34}$

The theist might discharge this lightened burden of proof in at least three ways:

(a) An argument for the existence of God would, of course, do the trick, since, a fortiori this would establish that God is possible.

(b) An account justifying an inference from conceivability to possibility in this case would also suffice, granting (plausibly, I think) that an essentially unsurpassable being is conceivable.

(c) The theist might be able to offer a Plantinga-style story about how $\mathrm{G}$ might be properly basic for the theist, given certain conditions. Presumably, this goal would be easier to achieve than Plantinga's stated goal of showing that propositions like "God loves me" can be properly basic.

Any or all of these approaches, if successful, could justify the theist in rejecting P1 or P2 from the inconsistent set, instead of G. And this is so even if the theist grants everything Rowe says in defence of B.

\subsection{DiRECT ATTACKS ON P1OR P2}

The most obvious way for the theist to respond is with a direct attack on P1 or P2. Any such move, however, must provide independent reason for rejecting one of these principles: it is question-begging to reject their conjunction merely because it precludes G (granting NPW). ${ }^{35}$ An attack on P1 or P2 may take one of two forms: it may suggest that their conjunction is unmotivated (or defeated) by reflection on ordinary human cases, ${ }^{36}$ or it may allege that their conjunction is implausible in the divine case. In what follows, I consider only the latter alternative, only with respect to $\mathrm{P} 1$.

First, though, two important clarifications must be noted with respect to the overall axiological status of a world: one concerns the role of God's existence, and the other concerns the role of God's actualizing activity. Rowe is prepared to concede that, quantitatively-speaking, any world that includes God's existing is infinitely-good. But Rowe plausibly suggests that worlds may still differ in qualitative degree of goodness (40-52). In effect, then, Rowe proposes that world-goodness be considered independently of the quantity of good contributed to a world by God's existence in it. I now add a related restriction concerning God's actualizing activity. The theist might initially be inclined to suppose that the goodness of the world-actualizing action is itself a contributing factor to the overall value of the resulting world. But, given the ceteris paribus clause, this would render P1 trivially true, since, by definition, the state of affairs consisting in a world-actualizing action is included in the maximally compossible state of affairs that comprises that world. Since P1 is intended to be a substantive claim, it is reasonable for the theist to consider the value of a world independently of whatever goodness-conferring role might be played by the relevant actualizing activity. So, when evaluating the axiological status of a world, the theist can legitimately set aside the quantitatively infinite goodness contributed to a world by God's existence in it, and whatever goodness is contributed to a world by God's actualization of it.

I now sketch two ways for the theist to reply to P1. First, the theist might support, on independent grounds, the intuition that on NPW, some worlds just are good enough for God to actualize, even though all of these worlds are surpassed. Theists like Langtry, Kretzmann, Morris, Wainwright, the Howard-Snyders, and Hasker (and even atheists like Bruce Russell) all seem to share this intuition, but so far as I know, none offers an independent argument for it. Such an argument would show that although it is a necessary truth that the outcome of God's actualizing action could be better (on NPW), with respect to some worlds it is false that God's actualization of them would comprise a better action. This would constitute a defeater for P1. 
The theist might also object to P1 by appeal to considerations about free will. Surely an important contributor to the overall axiological status of a world is the worth of the actions performed by free moral agents in that world. But given libertarian freedom (which many theists accept) it follows that a significant contributor to the overall status of a world is, quite simply, outside of God's control. ${ }^{37}$ This may suggest that it is possible for the product of God's actualizing activity to have been better, even though God's action (in weakly-actualizing the world and the free moral agents it contains) could not have been better. ${ }^{38}$ If so, then P1 can be rejected. 39

\subsection{ESSENTIAL UNSURPASSABILITY AND ESSENTIAL UNSURPASSEDNESS}

As I have characterized it, Rowe's argument means to defend the conclusion that on NPW, the doctrine of essential divine unsurpassibility is incoherent. Perhaps many theists would be unwilling to sacrifice this view, and should therefore develop some of the other three responses characterized above. But it may be worth considering, in conclusion, how else a theist might characterize God's perfections, were she to concede that essential unsurpassability is incoherent on NPW. 40

I take there to be an important difference between the idea that God is essentially unsurpassable and the idea that God is essentially unsurpassed. The former view maintains that God is not surpassed by any being in the actual world, and further that God is not surpassed by any being in any other possible world. In contrast, the latter view holds merely that God is not surpassed by any being in the actual world. I tentatively suggest that the theist can plausibly understand God's perfections in the latter sense. ${ }^{41}$

The standard response to a move like this is to say that there is something deficient, or unworthy (of worship, for example) about an essentially unsurpassed God. Could such a charge plausibly be developed?

(1) It might be suggested that, on this view, God is deficient simply for not exemplifying the property of being essentially unsurpassable. But this charge is a non-starter, once it is conceded that that property is incoherent: no being can be faulted for failing to exhibit such an attribute. (For similar reasons, it cannot plausibly be maintained, on this view, that only essentially unsurpassable beings are worthy of worship.)

(2) It might be claimed that an essentially unsurpassed God is deficient in virtue of being surpassed in some world by a being other than God. But the theist can stipulate this to be impossible, by maintaining the traditional view that God is a necessary being. If God is a necessary being, then God exists in every world, and given that God is unsurpassed in every world, it follows that no being other than God can possibly surpass God. Further, the theist can claim that God, in each world, is the cause of that world's being actual (thus preserving the traditional notion that God is, necessarily, the creator and sustainer of all that is).

(3) It might be urged that this view objectionably countenances worlds in which God is not particularly powerful, knowledgeable, good, or rational, but nevertheless surpasses all other beings in that world. But the theist can refine the view to hold that for those attributes with intrinsic maxima (e.g.: omnipotence and omniscience) God necessarily possesses these attributes maximally. So, for example, there are no worlds in which God is weak, but still just a bit more powerful than anybody else in that world. Conceding for the sake of argument that either goodness or rationality (or both) are attributes that cannot possibly be possessed maximally, the theist can further stipulate that there is some objective threshold of divine goodness and rationality such that worlds in which God's goodness or rationality would fall below this threshold simply are not possible. This move relies on Morris' suggestion that God is the delimiter of possibilities - a view which Rowe endorses. ${ }^{42}$ 
(4) Relatedly, it might be said that this view objectionably countenances the notion that God might actualize worlds which are themselves not good overall. Again, however, the theist can use Morris' idea that God is the delimiter of possibilities: given God's necessary existence and essential characteristics, worlds which fail to be good overall, despite their conceivability and apparent possibility, simply are not possible. And if they are not possible, a fortiori they cannot be actualized.

(5) It might be held that this view objectionably suggests that God is not immutable. To be mutable is to be possibly different than one is, and since God is better in some worlds than others, this definition is satisfied. First, I note in response that the idea that God could 'change', in this sense, is not a special problem here: since Aristotle, immutability has been insisted on precisely because of a desire to maintain a maximal conception of the divine perfections. But more importantly, I don't see how this charge is a serious problem for the theist. On the picture I've sketched, the theist can consistently maintain that God does not change within any world, and God that never fails to be omnipotent, omniscient, good, loving, and the creator and sustainer of all that is. What more could be desired?

(6) One might think that some problem concerning personal identity lurks here: God, on this conception, has at least one property to a much (even infinitely) greater degree in some worlds than in others. But this doesn't seem enough to breach personal identity: God in every world has all other perfections maximally, and God plays the same role in every possible world. Surely this is enough to secure a robust notion of God's identity across worlds.

On this proposal, then, every member of the set of possible worlds is good overall, God exists necessarily, is the creator and sustainer of all that is actual, is maximally powerful and knowledgeable, and is surpassed by no other being. But for any world w, there is a world $\mathrm{x}$ in which God is better, either with respect to goodness or rationality, than God is in w. (And relatedly, while God is worthy of worship in w, God might be still more worthy of worship in x.) If this picture is coherent, and if none of the objections mentioned so far is successful, what possible complaint might creatures lodge against God?

It might be thought that creatures could sensibly complain about this world's being actual, instead of some world in which God is better than God is. But this complaint may not be legitimate. As noted, according to this proposal every possible world is good overall, and the theist can also stipulate, on similar grounds, that every possible world is an Adams World: a world in which

(a) every individual creature is at least as happy on the whole as it would have been in any other possible world in which it could have existed; and

(b) no creature has a life so miserable on the whole that it would have been better for that creature had it never existed. ${ }^{43}$

Adams argues, plausibly, that if God actualizes such a world, God harms no creature, and God displays no unkindness or wrongdoing towards anyone. It seems, then, that on this picture, creatures have no grounds for complaint against God - even if God could have been better in some way.

Much more could be said about this notion of essential divine unsurpassedness. But for the moment, I conclude merely that this idea is not obviously incoherent or objectionable, and I tentatively recommend that the theist develop it further, if Rowe-style arguments for the impossibility of essential divine unsurpassability are conceded to be sound. But I have also offered suggestions for other ways in which the theist might resist Rowe's central argument in Can God Be Free? 


\section{NOTES}

${ }^{1}$ All page references in the text are to William L. Rowe, Can God Be Free? (New York: Oxford University Press, 2004). For other presentations of this point, see pages 92, 98, 112, and 130-1.

${ }^{2}$ Arguments in this vein are also advanced by Philip Quinn ("God, Moral Perfection, and Possible Worlds", in God: The Contemporary Discussion, [F. Sontag and M.D. Bryant, Eds.], New York: The Rose of Sharon Press, Inc. (1982): 197-213); R. K. Perkins, ("An Atheistic Argument from the Improvability of the Universe", Noûs 17 (1983): 239-250); Richard Gale, (On The Existence and Nature of God, Cambridge: Cambridge University Press (1991): 30-31); Stephen Grover ("Why only the Best is Good Enough", Analysis 48 (1988): 224, "This World, 'Adams Worlds', and the Best of All Possible Worlds", Religious Studies 39 (2003): 145-163, and "Rival Creator Arguments and the Best of all Possible Worlds", Sophia 43 (2004): 101-114); J ordan Howard Sobel, (Logic and Theism: Arguments for and Against Beliefs in God, Cambridge: Cambridge University Press (2004): 468ff); and Eric Wielenberg, ("A Morally Unsurpassable God Must Create the Best", Religious Studies 40 (2004): 43-62).

${ }^{3} \mathrm{~J}$ ordan Howard Sobel (op. cit) makes this move.

${ }^{4}$ My replacement for Rowe's A claims merely that it is possible that there should exist a being who is essentially unsurpassable in power, knowledge, goodness, and rationality. I do not mean to suggest hereby that a contingent being could be unsurpassable in every respect (fans of ontological arguments, after all, would surely deny this). Instead, I mean only to express the claim that this being exists in at least one possible world. As we will see, Rowe's argument can be understood as intending to reduce to absurdity (given certain assumptions) the claim that God necessarily exists, which is a conclusion some theists might be willing to accept. As I express the argument, however, the conclusion is that God's existence (as an essentially unsurpassable being) is impossible. Fewer theists will be willing to accept this conclusion. It should be noted, however, that weakening Rowe's A in this fashion lightens the burden of proof for the theist who wants to insist on this claim on independent grounds. For more on this, see Section 2.2.

5 Or outcome, consequence, or result.

${ }^{6}$ One exegetical reason for distinguishing P1 and P2 is that some of Rowe's interlocutors criticize the former, while others reject the latter. For example, Bruce Langtry means to reject P1, while Thomas Morris criticizes P2. I claim that both of these arguments fail, in "William L. Rowe's A Priori Argument for Atheism" (forthcoming in Faith and Philosophy 22, 2005).

${ }^{7}$ Michael Almeida's contributions at the 2005 Central APA helped me to appreciate this point.

8 Several authors, including Rowe, refer to creatable possible worlds. Strictly speaking, though, worlds are states of affairs which can neither be created nor destroyed, and so I have replaced creatable (in C) with actualizable (in NPW).

${ }^{9}$ A 'prime world' is a world (a) that God can actualize; and (b) than which none better is actualizable by God. This expression is due to Bruce Langtry, "God and the Best", Faith and Philosophy 13 (1996): 311328. NPW differs from NBW (the view that there is no best world) only if there are possible worlds that God does not have the power to actualize. For an argument to this effect, see Alvin Plantinga, The Nature of Necessity, Oxford: Clarendon Press, 1974, 169-184.

10 Two clarifications are needed here:

(1) This proposition may sound consequentialist, but it is not wedded to any particular account of the relationship between the goodness of outcomes and the goodness of actions. For more in this vein, see Earl Conee, "The Nature and Impossibility of Moral Perfection", Philosophy and Phenomenological Research 54 (1994): 821.

(2) The consequent P1 claims that it is possible for an action to have been 'better', and the consequent of P2 claims that it is possible for a being to have been 'better'. Some authors, like Rowe, 
understand these claims to concern moral surpassability, but they may equally be understood to concern rational surpassability (as, for example, Jordan Howard Sobel does.) Everything I say below is consistent with both interpretations of $\mathrm{P} 1$ and $\mathrm{P} 2$.

A third clarification (concerning the goodness-conferring role of God's actualizing activity) will be discussed in Section 2.3., below.

11 This inconsistent set can be used to construct a reductio of the following form:

(1) There possibly exists a being who is essentially unsurpassable in power, knowledge, goodness, and rationality. [assumption for reductio]

(2) On NPW, it is always possible for the product of the world-actualizing action of this being to have been better.

P1 If it is possible for the product of a world-actualizing action performed by some being to have been better, then, ceteris paribus, it is possible for that being's action to have been better.

(3) Therefore, on NPW, it is always possible for the world-actualizing action of this being to have been better.

P2 If it is possible for the world-actualizing action performed by some being to have been better, then, ceteris paribus, it is possible for that being to have been better.

(4) Therefore, on NPW, it is always possible for the being who is essentially unsurpassable in power, knowledge, goodness, and rationality to have been better.

(5) But it is not possible for such a being to have been better.

(6) Therefore, on NPW, it is false that there possibly exists a being who is essentially unsurpassable in power, knowledge, goodness, and rationality, who has created the world.

Of course, the same set could also be used to construct a valid reductio of the conjunction of $\mathrm{P} 1$ and $\mathrm{P} 2$, or of NPW.

12 Rowe thinks that this is an awkward dilemma for the theist: she must either give up (or modify) her traditional theistic belief, or deny NPW. And Rowe argues in Chapter 5 that, on the latter horn of the dilemma, God cannot be thought free, since if there is a (unique) prime world, God cannot fail to actualize it.

13 Elsewhere, I have replied to other critics of Rowe's argument: I respond to Thomas Morris, Bruce Langtry, and Daniel and Francis Howard-Snyder in "William L. Rowe's A Priori Argument for Atheism", and I reply to the Howard-Snyders and to Edward Wierenga in "God and the Hypothesis of No Prime Worlds", forthcoming in the International J ournal for Philosophy of Religion.

${ }^{14}$ I thank both Bills for their generosity in making available to me their various conference presentations on this material, and for their kindness in corresponding with me via email on this subject over the past several years.

${ }^{15}$ Providence, Evil, and The Openness of God, New York: Routledge, 2004.

${ }^{16}$ Morris says:

But failing to do the best you can is a flaw or manifests an incompleteness in moral character ... only if doing the best you can is at least a logical possibility. If doing the best he can in creating a world is for God an impossibility, given the range of omnipotence and the nature of those considerations making the notion of the best of all possible worlds an incoherence, then not doing his best in creating cannot be seen as a flaw or as manifesting an incompleteness in the character of God. The notion of a perfect expression of an 
unsurpassable character would then itself be an incoherence ("Perfection and Creation", 244).

17 "The Freedom and Goodness of God", in Providence, Evil, and The Openness of God, 172 (emphasis added).

18 ibid., 173, emphasis added. The position expressed in these quotations is closely-related to claims made by George Schlesinger and William Wainwright. The former holds that "If ... no matter what changes are introduced, in any new situation there is exactly as much reason to complain as before, there is no right to demand that the present situation be replaced by another" (Religion and Scientific Method, Boston: D. Reidel Publishing Company, 1977, 65.) The latter says that “.. a type of complaint which is always in place is never in place. A complaint is only legitimate when the person whose conduct is criticized could have acted in such a way that he or she would not be exposed to a complaint of that type" (Philosophy of Religion, Scarborough: Wadsworth, 1999, 92). Rowe denies that Hasker's argument is fundamentally similar to Wainwright's (117), but his reasons for saying this are not clear to me. (Thanks to David Widerker for reminding me about Schlesinger.)

19 Providence, Evil, and The Openness of God, 205.

20 This premise is secured by a formal argument in "The Freedom and Goodness of God", ibid., 172-173.

${ }^{21}$ As I see it, the central exegetical question is whether Rowe endorses premise (3), and the central evaluative question is whether he should. In footnote 37 (228), Hasker claims that both (2) and (3) are instances of a general principle which Rowe does endorse:

A: If $\mathrm{S}$ is a logically impossible state of affairs, then the fact that a being does not bring about $\mathrm{S}$ does not entail that the being in question lacks perfect power or perfect goodness (412).

It's not obvious to me that (3) is an instance of (A). But as I argue below, even if Rowe does endorse (3), he shouldn't: this claim may plausibly be rejected, even if (2) is accepted.

22 This story is imagined in several other places $(102-3,125,127,134)$.

${ }^{23}$ I take it that the 'Mary' story is meant to support this distinction (111).

24 Providence, Evil, and The Openness of God , note 36, 228, emphasis added.

25 Of course, Hasker does not mean the latter to be understood as blaming God for failing to both do and not do the same thing. (See "The Freedom and Goodness of God", 171).

26 ibid., 172.

${ }^{27}$ Similarly, of course, God's omnipotence is not diminished by an inability to construct square circles.

28 Three points:

(a) As Rowe rightly points out in his reply to Wainwright (118), 'fault-talk' is a little misleading. It's not that God is being faulted; instead, a reason is being offered for thinking that no being can be essentially unsurpassable on NPW. To think otherwise may be objectionably question-begging, by supposing that God is possible on NPW.

(b) My reply to Hasker echoes comments Rowe makes in reply to Kretzmann (91) and to Morris (101). It's not clear to me why Rowe didn't make the same move in reply to Hasker.

(c) I presume that Hasker will be inclined to deny that the failure to contravene any necessary truth can be reason for thinking a being surpassable. But consider this. Suppose that some creaturely essences suffer from transworld depravity. For such creatures, it is a necessary truth that, if their essence is instantiated, they freely do moral wrong on at least one occasion. But surely we wouldn't want to deny 
that their failure to contravene this necessary truth is to their relative moral discredit. Such beings cannot possibly avoid the fault of going wrong at least once in worlds in which they exist, and this fact constitutes excellent reason for thinking that these beings are morally surpassable. So not all failures to contravene necessary truths are morally-neutral.

${ }^{29}$ Or, equivalently, suppose that the theist grants that the reductio of $\mathrm{G}$ displayed in note 11 is valid. (I see no way for the theist to avoid this.)

${ }^{30}$ I will not consider whether the theist can plausibly give up NPW. But here is what I take to be required for this to work: (a) the theist must defeat the a priori reasons typically offered for NPW; and (b) the theist must either argue, in the spirit of Adams, that God can (consistently with his essential attributes) actualize a world less than the best, or argue, in the spirit of Leibniz, that this is the best of all possible worlds. I take it that the latter disjunct of (b) is the more promising option for the theist. But Rowe has likely done more than any other contemporary critic of theism to show that it is reasonable to believe, on a posteriori grounds, that this world features gratuitous evil, and if he is right, this constitutes good reason to think that the actual world is not the best possible. (Of course, Rowe's arguments have not gone unchallenged. For my views on this, see "Absence of Evidence and Evidence of Absence", forthcoming in Faith and Philosophy.) Finally, as Rowe rightly insists, even if it can plausibly be claimed that this is the best of all possible worlds, the theist still owes either an account of how God could freely choose to actualize it, or else an explanation of why freedom in world-actualization is not essential to theism.

${ }^{31}$ Here are five examples:

(a) ".. if an omniscient being creates a world when it could have created a better world, then that being has done something less good than it could do (create a better world). But any being who knowingly does something (all things considered) less good than it could do falls short of being the best possible being" (89, and "Can God Be Free?, 411).

(b) "Following Philip Quinn, I'm inclined to think that if an all-powerful, all-knowing being creates some world other than the best world it could create, then it is possible that there should exist a being morally better than it is. For it would be possible for there to be an omnipotent being who creates the best world that the first being could create but did not ... If, however, a being were to create a world when there is a better world it could create, then it would be possible for there to be a being morally better than it" (82-3).

(c) "Other things being equal, if an omnipotent, omniscient being's degree of goodness is such that he judges as acceptable for creation a world that is less good than any world which another omnipotent, omniscient being, given its degree of goodness, judges as acceptable for creation, this fact constitutes evidence that the first being is less good than the second (and hence isn't perfect)" (115).

(d) Rowe explicitly labels the following claim an assumption: "A3: The degree of goodness of a world that is acceptable for creation by an omnipotent, omniscient, good being is indicative of the degree of goodness of that being" (119).

(e) Finally, Rowe often considers the thought-experiment of a being's actualizing the least member of some set of good actualizable worlds: he thinks it obvious that such a being is surpassable (102-3, $109,125,127,134)$. This seems more like a heuristic device than an independent argument for Principle B.

32 “Can God Be Free?”, 418, emphasis added.

${ }^{33}$ This position could be maintained even if the theist were to grant that none of the known challenges to B succeed.

${ }^{34}$ Equal reasons will block Rowe's argument; better reasons will defeat it.

35 As I see it, Langtry, Morris, and Menssen and Sullivan commit this mistake. I develop this charge against Langtry and Morris in "William L. Rowe's A Priori Argument for Atheism", and Rowe nicely develops this charge against Menssen and Sullivan in Chapter 6, Section VII. Hasker's argument, discussed in Section 1, is an independent attack on the conjunction of P1 and P2. 
${ }^{36}$ Hasker says that these principles cannot very well stand all by themselves as principles concerning world-actualizing beings and their actions: they must surely be grounded in our beliefs about ordinary human actions, outcomes, and agents (Providence, Evil, and The Openness of God, 168). If he is right, then the theist should carefully consider

P1h If it is possible for the product of an action performed by some human being to have been better, then, ceteris paribus, it is possible for that being's action to have been better; and

P2h If it is possible for the action performed by some human being to have been better, then, ceteris paribus, it is possible for that being to have been better.

And this project could be subdivided into looking at rationality and looking at morality: the word 'better' in the consequents could be understood in either sense.

${ }^{37}$ A potential objection: the moral worth of the (libertarian) free actions of created agents cannot properly be considered part of the product, or outcome, or result, of God's world-actualizing action. I doubt, though, that this objection can plausibly be sustained.

38 Brian Leftow develops something like this move in a series of three forthcoming papers in Religious Studies: "No Best World 1", "No Best World 2", and "Perfect Benevolence".

39 Actually, this is a bit hasty. It is reasonable to suppose that certain world-good-making properties are moral, while others are non-moral. The considerations about libertarian free will I just mentioned show, at most, that there are moral ways in which a world could be better, over which God has no control. But one might reply that this does not show that God's action could not possibly be surpassed: perhaps God could still improve any world in non-moral ways. As far as I can tell, then, the theist needs to show that there is an upper bound on the non-moral ways in which God could improve a world, beyond which better worlds are possible, but not (entirely) up to God to actualize. This, I think, would show that P1 is not a necessary truth.

40 There are other arguments for the conclusion that essential unsurpassability is impossible. See, for instance, Theodore Guleserian's "Can Moral Perfection Be an Essential Attribute?", Philosophy and Phenomenological Research 46 (1985): 219-241, and Earl Conee, op. cit. Brian Leftow responds to the former in "Necessary Moral Perfection", Pacific Philosophical Quarterly 70 (1989): 240-260.

${ }^{41}$ William Wainwright suggests a similar move in his Philosophy of Religion (8), and in his contribution at the 2005 Central APA. Others have also argued in this vein. Gulesarian, for example, offers a more radical account of non-essential moral perfection in op. cit., 237-239. And I take it that Hasker's distinction between intrinsic and productive goodness in "The Freedom and Goodness of God" is meant to support a revised understanding of divine perfection, according to which God is not essentially unsurpassable in all respects. Hasker says, after all, that Rowe

... is certainly right to conclude that God as defined by Rowe does not exist. And if he finds this definition sufficiently compelling, it may seem to him that the unqualified conclusion, "God does not exist" [on NPW], is warranted. The history of theistic reflection, however, tells a different story. It has happened repeatedly that religious thinkers have come to realize that a particular, initially plausible conception of some divine attribute leads to incoherence. For almost all of these thinkers this realization has led, not to the conclusion that God does not exist, but to a modification in the understanding of the attribute in question (175).

42 Morris says:

If there is a being who exists necessarily, and is necessarily omnipotent, omniscient, and good, then many states of affairs which otherwise would represent genuine possibilities, 
and by all non-theistic tests of logic and semantics do represent possibilities, are strictly impossible in the strongest sense. In particular, worlds containing certain sorts or amounts of disvalue or evil are metaphysically ruled out by the nature of God, divinely precluded from the realm of possibility (Anselmian Explorations: Essays in Philosophical Theology, Notre Dame: University of Notre Dame Press, 1987, 48).

Rowe endorses this move (164), although he tries to reverse it against the theist, by claiming that certain possibilities (like the unrestricted possibility of God actualizing a better world) are delimiters of necessity: they show that God cannot be essentially unsurpassable.

43 Robert Adams, "Must God Create the Best?", The Philosophical Review 83 (1972): 317-322. The term 'Adams World' is, I believe, due to Stephen Grover, in 'This World, 'Adams Worlds', and the Best of All Possible Worlds", Religious Studies 39 (2003): 145-163. 